\title{
KONSEP KEPEMILIKAN DAN DISTRIBUSI PENDAPATAN DALAM SISTEM EKONOMI ISLAM
}

\author{
Muhammad Kambali \\ STAI Al-Azhar Menganti Gresik \\ hambali236@gmail.com
}

\begin{abstract}
In Islamic economics, the human desire to collect and acquire wealth is the nature of every human being. Humans were created by God, both physically and spiritually. Therefore, their needs must be met. The human urge to acquire wealth is nothing but caused by the existence of human physical needs in order to continue to exist in the world. This study aims to describe the conception of ownership and income distribution in the Islamic economic system. Data were collected by reading and reviewing literature related to the research focus and analyzed using descriptive analysis techniques. The results of this study state that Islam does not prohibit individuals from obtaining wealth, but Islam only regulates the mechanism for acquiring these assets. In other words, the existence of individual property rights is recognized by Islam. In addition, Islam also recognizes the existence of public ownership and state ownership. The concept of income distribution in the Islamic economic system requires two things so that justice as an Islamic economic principle is manifested in it. These two things are the balance of wealth in society and the prohibition of hoarding of wealth.
\end{abstract}

Keywords: Islamic Economics, Ownership, Income Distribution

Abstrak: Dalam ekonomi Islam, keinginan manusia untuk mengumpulkan dan memperoleh harta kekayaan adalah fitrah setiap manusia. Manusia diciptakan Allah meliputi jasmani dan rohani. oleh sebab itu, kebutuhannya haruslah terpenuhi. Dorongan manusia untuk memperoleh harta kekayaan adalah tidak lain di sebabkan oleh adanya keberadaan kebutuhan jasmani manusia agar tetap eksis di dunia. Penelitian ini bertujuan mendikripsikan konsepsi kepemilikan dan distribusi pendapatan dalam sistem ekonomi Islam. Data dihimpun dengan membaca dan menelaah literatur yang berkaitan dengan fokus pemelitian dan dianalisis dengan teknik deskriftif analisis. Hasil penelitian ini menyatakan Islam tidak melarang individu-individu untuk memperoleh harta kekayaan, melainkan Islam hanya mengatur mekanisme pemerolehan harta kekayaan tersebut. Dengan kata lain, keberadaan hak milik individu diakui oleh Islam. Selain itu, Islam juga mengakui keberadaan kepemilikan umum dan kepemilikan negara. Konsep distribusi pendapatan dalam sistem ekonomi Islam mengharuskan pada dua hal supaya keadilan sebagai prinsip ekonomi Islam termanivestasi didalamnya. Dua hal tersebut adalah adanya keseimbangan harta dalam masyarakat dan larangan adanya penimbunan harta.

Kata Kunci: Ekonomi Islam, Kepemilikan, Distribusi Pendapatan 



\section{A. Pendahuluan}

Islam sebagai agama universal, bukan hanya mengatur hubungan manusia dengan Tuhan (hablum minallah/vertikal) melainkan juga mengatur hubungan dengan sesama manusia (hablum minannas/horizontal). Manusia diciptakan Allah SWT. semata-mata hanya untuk beribadah. Hal ini, ditegaskan dalam Al-qur'an S. adz-Dzariyat : 56 yang berbunyi :

$$
\text { وَمَا خَلَقَتُ الْجِنَّ وَالْإِنْسَ إِلَّ لِيَعْبُدُونِ(الذريات : 56) }
$$

Artinya :"Dan Aku tidak menciptakan jin dan manusia melainkan supaya mereka menyembah-Ku".(QS. Adz-Dzariyaat : 56) ${ }^{1}$

Dalam pandangan para ulama, makna "ibadah" dalam ayat tersebut, di artikan dalam dua macam, yaitu ibadah yang menyangkut hubungan manusia dengan Allah SWT yang selanjutnya dikenal dengan istilah "Ibadah Mahdhah" dan ibadah yang menyangkut hubungan manusia dengan manusia dan manusia dengan alam sekitarnya yang selanjutnya di kenal dengan istilah "Ibadah Ghairu Mahdhah".

Ekonomi Islam, pada awal mulanya merupakan lahir dari perkembangan fiqh muamalah. Dalam kajian fiqih muamalah ditemukan aturan hukum Islam yang menyangkut hubungan sesama manusia, yang terdiri atas aturan tentang jual beli, sewamenyewa, upah, perjanjian/kontrak, perdagangan, titipan dan harga. ${ }^{3}$ Walaupun demikian, kajian tentang fiqih muamalah masih banyak yang memposisikannya sebagai hukum perdagangan saja. Bukan diposisikan sebagai kajian yang integral sebagai ilmu ekonomi.

Muara dari segala bentuk muamalah dalam Islam pada dasarnya adalah berasal dari Nabi Muhammad saw. ketika beliau hijrah dari Makkah ke Madinah. Di Madinah

\footnotetext{
${ }^{1}$ QS. Adz-Dzariyaat (5I): 56

${ }^{2}$ Ahmad Mushthafa al-Maraghi, Tafsir al-Maraghi, Alih Bahasa Bahrun Abu Bakar, jus 27, cetakan ke-2, (Semarang:Toha Putra,I992), 24

${ }^{3}$ A.Qodri Azizy, Membangun Fondasi Ekonomi Umat: Meneropong Prospek Perkembangannya Ekonomi Islam, (Yogyakarta : Pustaka Pelajar, 2004), 176.
}

Volume. 9/No. 2/Juli 202I A1-Iqtishod | 127 
Konsep Distribusi Pendapatan ....

Rasulullah meletakkan fondasi hubungan muamalah dalam Islam. Termasuk didalamnya, yang pada masa kontemporer ini mencuatnya gagasan negara Islam atau ekonomi Islam. ${ }^{4}$

Wacana ekonomi Islam, mencuat dan mendapat perhatian dari kalangan pemikir Islam dimulai pada awal tahun I970-an. Hal ini ditandai dengan perintisan perbankan Islam oleh Nawar Iqbal Qureshi pada tahun 1946 dan Naiem Siddiqi pada tahun 1948 serta Mahmud Muhammad pada tahun I952. Disusul al-Maududi (1950) dan Mahmud Uzair melalui karyanya “A. Ground Work for Interest free Banking” pada tahun I955. ${ }^{5}$

Memasuki tahun 1970-an, wacana ekonomi Islam makin mendapatkan perhatian. Semisal di Amerika Serikat lahir organisasi "The Association of Muslim Social Scientist (AMSS) atas prakarsa "The Musliem Student's Association of The United States and Canada (MSA), sebagai wadah yang membicarakan sistem ekonomi, sosial dan pendidikan menurut ajaran Islam. Pada tahun 1976 di Makkah diselenggarakan "International Conference on Islamic Economics”. Kemudian dilanjutkan pada tahun berikutnya 1977 di London juga diselenggarakan International Economic Conference on Musliem World and The Future Economic Order". Sedangkan di Indonesia sendiri baru muncul sekitar 1982 di Ujung Pandang.

Pada hakekatnya, ekonomi Islam juga tidak jauh berbeda dengan ekonomi pada umumnya (konvensional). Ekonomi Islam, juga mengkaji tentang prilaku manusia dalam menjatuhkan pilihan dan penggunaan sumber daya alam produktif. Hanya saja, ekonomi Islam dalam menjatuhkan pilihan dan penggunaan sumber daya alam senantiasa didasarkan pada ajaran-ajaran Islam yang terdapat dalam al-Qur'an dan al-Hadits. Dengan kata lain, ekonomi Islam merupakan ilmu pengetahuan sosial yang mempelajari masalah-masalah ekonomi yang diilhami oleh nilai-nilai Islam.

Ekonomi Islam memandang harta kekayaan yang terdapat di bumi dan alam adalah ditujukan semata-mata untuk manusia. Manusia diciptakan oleh Allah SWT sendiri atas dua unsur yaitu jasmani dan rohani. Oleh sebab itu keberadaan manusia di bumi ini, tidak

\footnotetext{
5 Abdul Mughist, Epistemologi Ilmu Ekonomi Islam, Hermeneia : Jurnal Kajian Islam Interdisipliner, vol. 2, No. 2, Juli-Desember, h. 174
}

${ }^{4}$ M. Hasbin Amiruddin, Konsep Negara Islam Menurut Fazlur Rahman, (Yogyakarta:UII-Press, 2000), 2-3.

I28| Al-Iqtishod Volume. 9/No. 2/Juli 202I 
akan mampu bertahan ketika kebutuhan yang dipenuhi adalah ruhani semata. Sehingga dari itu, Islam juga memerintahkan manusia untuk memenuhi kebutuhan jasmaninya. Akan tetapi bukan berarti ketika Islam memerintahkan manusia untuk memenuhi kebutuhan jasmaninya, manusia bisa bertindak sesuka hatinya. Dalam pandangan Islam pemenuhan kebutuhan jasmani yang diwujudkan melalui pemerolehan harta dan kekayaan dengan jalan bekerja dan berusaha adalah semata-mata untuk menunjang ibadah kepada Allah SWT. Dengan kata lain, harta dan kekayaan di mata Islam bukanlah yang utama. ${ }^{6}$

Karakteristik-fundamental yang membedakan antara ekonomi Islam dengan sistem ekonomi lainnya (sosialis, kapitalis, feodalis, komunis) adalah bahwa Islam melihat kegiatan ekonomi sebagai sarana pemenuhan kebutuhan jasmani manusia, hanya ditujukan untuk mencapai kebahagiaan dan keselamatan akhirat. Eksistensi manusia hanyalah memiliki makna bila seluruh kegiatannya di dunia didedikasikan untuk Allah SWT.7 Penggambaran tentang hal ini, sejalan dengan tujuan penciptaan manusia.

Dalam al-Qur'an Allah swt menyatakan :

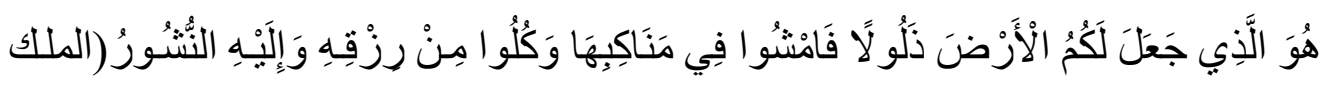

Artinya :"Dialah Yang menjadikan bumi itu mudah bagi kamu, maka berjalanlah di segala penjurunya dan makanlah sebahagian dari rezki-Nya. Dan hanya kepada-Nya-lah kamu (kembali setelah) dibangkitkan."(QS. al-Mulk : I5)8

Dari ayat di atas, nampaklah bahwa harta merupakan bagian yang sangat penting dalam kehidupan setiap manusia. Islam tidak melarang manusia untuk memperoleh harta, akan tetapi Islam juga tidak membenarkan kesewenang-wenangan manusia dalam memperoleh harta, seperti peniadaan akan larangan halal dan haram.

Pemerolehan harta kekayaan dalam Islam, selain dengan jalan bekerja, Bisa jadi didapatkan dari orang lain seperti pemerolehan harta melalui hibah dan hadiah. Selain itu,

${ }^{6}$ Mahmud Abu Saud, Garis-Garis Besar Ekonomi Islam, Alih Bahasa Syed Ahmad Ali , (Jakarta: Gema Insani Press, I99I), I7

${ }^{7}$ M. Amin Rais, Cakrawala Islam:Antara Cita Dan Fakta, (Bandung: Mizan, I99I), 96

${ }^{8}$ QS. al-Mulk (67) : I5 
Konsep Distribusi Pendapatan ....

Islam juga mengakui adanya harta yang didapatkan dengan jalan waris. Di dalam al-Qur'an surat An-Nisa : II Allah swt menyatakan :

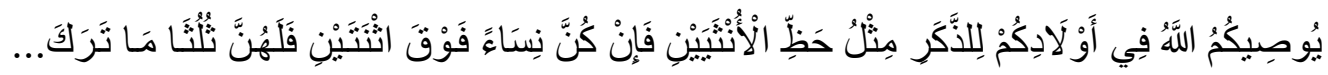

(النساء: (II ) (الن)

Artinya : "Allah mensyari atkan bagimu tentang (pembagian pusaka untuk) anakanakmu. Yaitu: bahagian seorang anak lelaki sama dengan bahagian dua orang anak perempuan; dan jika anak itu semuanya perempuan lebih dari dua, maka bagi mereka dua pertiga dari harta yang ditinggalkan..."(QS. An-Nisa : I I). ${ }^{9}$

Dengan demikian, pokok pembahasan yang terdapat dalam ekonomi Islam adalah berkaitan dengan kepemilikan (property), pengelolaan kepemilikan dan distribusi kekayaan atau harta di tengah-tengah manusia. Ketiga pokok pembahasan inilah yang menjadi wilayah garapan dari ekonomi Islam. ${ }^{10}$ Dengan didasarkan pada nilai-nilai syar'i yang termaktup dalam Al-Qur'an dan As-Sunnah.

\section{B. Kajian Pustaka}

\section{Prinsip Dasar Ekonomi Islam}

Pada dasarnya, prinsip dasar ekonomi Islam terdiri atas tiga hal yaitu prinsip tauhid, khilafah dan al-'adalah (keadilan). ${ }^{11}$ Prinsip-prinsip ini tidak hanya menjadi kerangka kerja bagi Islam (ekonomi). Akan tetapi juga merupakan tujuan dan sumber utama maqashid dari syari' ah Islam.

Pertama, Tauhid. Merupakan fondasi utama dalam Islam. Tauhid merupakan dasar dari seluruh ajaran Islam yang menyatakan pada ke Esaan dan ke Mahaagungan kekuasaan Allah SWT. Dalam ranah ekonomi Islam, Tauhid merupakan pengakuan manusia atas penciptaan alam seisinya oleh Allah SWT. Sehingga keberadaan alam beserta seisinya bukan terjadi secara kebetulan

${ }^{9}$ QS. An-Nisa (4): II

${ }_{10}$ Taqyuddin An-Naabhani, Membangun Sistem Ekonomi Alternatif : Prespektif Islam, Alih Bahasa M. Mighfar Wachid, (Surabaya: Risalah Gusti, 2002), 50

${ }^{11}$ M. Umer Capra, Islam dan Tantangan Ekonomi: Islamisasi Ekonomi Kotemporer, Alih Bahasa Nur Hadi Ihsan, (Surabaya : Risalah Gusti, I999), 217

I30| Al-Iqtishod Volume. 9/No. 2/Juli 202I 
sebagaimana teori-teori dari sarjana barat yang mengkaji tentang asal-muasal alam semesta ini. ${ }^{12}$

Prinsip tauhid, juga mengajarkan pada manusia, bahwa segala sesuatu yang dimiliki oleh manusia termasuk didalamnya harta kekayaan adalah semata-mata berasal dari Allah SWT. yang bersifat nisbi/relatif. Sedangkan yang abadi dan mutlak hanya milik Allah swt saja. Dengan demikian, tauhid merupakan ruh/fondasi dari ekonomi Islam. ${ }^{13}$

Kedua, Khilafah. Dalam konsepsi ekonomi Islam, manusia merupakan khalifah Allah swt di bumi. Manusia diutus Allah swt ke bumi membawa misi menjadi seorang khalifah dalam arti sebagai wakil Allah SWT. dan pemakmur bumi. Alam seisinya sebagai hasil ciptaan Tuhan semata-mata hanya untuk manusia guna dikelola dan dimanfaatkan bagi kesejahteraan umat.

Dalam Al-Qur'an Allah SWT. berfirman :

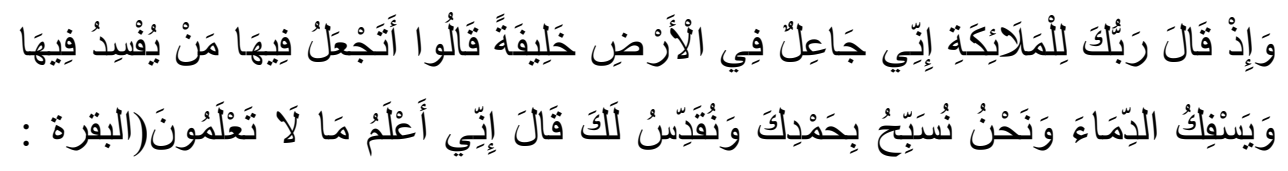

Artinya : "Ingatlah ketika Tuhanmu berfirman kepada para malaikat: "Sesungguhnya Aku hendak menjadikan seorang khalifah di muka bumi". Mereka berkata: "Mengapa Engkau hendak menjadikan (khalifah) di bumi itu orang yang akan membuat kerusakan padanya dan menumpahkan darah, padahal kami senantiasa bertasbih dengan memuji Engkau dan mensucikan Engkau?" Tuhan berfirman: "Sesungguhnya Aku mengetahui apa yang tidak kamu ketahui". (QS. Al-Baqarah : 30$).{ }^{14}$

Dari ayat tersebut, nampaklah bahwa alam dan segala seisinya merupakan anugrah Allah pada manusia. Kekayaan yang terkandung di dalam bumi

\footnotetext{
${ }^{12}$ Asal-muasal alam semesta dalam pandangan sarjana Barat sangat beraneka ragam, seperti Thales yang menyatakan pada dasarnya segala sesuatu itu berasal dari air, lain lagi dengan pandangan Heraklitos ataupun Phitagoras.

${ }_{13}$ Muhammad Kambali, "KRITIK EKONOMI ISLAM TERHADAP MEKANISME DISTRIBUSI PENDAPATAN DALAM SISTEM EKONOMI KAPITALIS,” Jurnal Studi Keislaman, 2015.

${ }^{14}$ QS. Al-Baqarah (2) : 30
} 
Konsep Distribusi Pendapatan ....

diperuntukkan bagi manusia untuk dikelola agar mempunyai daya guna dan untuk kesejahteraan umat manusia. Walaupun demikian, dalam pengelolaan isi bumi, Islam menghendaki adanya prinsip keseimbangan (tawazun). Prinsip keseimbangan yang dimaksudkan dalam hal ini adalah keseimbangan antara urusan dunia dan urusan akhirat. ${ }^{15}$

Implikasi dari prinsip khilafah ini adalah $:{ }^{16}$

a. Persaudaraan universal

Implikasi pertama dari prinsip khilafah ini adalah lahirnya persatuan dan persaudaraan antara umat manusia. Dalam konteks manusia sebagai makhluk sosial, maka pada dasarnya setiap individu adalah seorang khalifah juga. Oleh sebab itu, sikap saling menolong dan kerjasama senantiasa menjadi dasar setiap manusia dalam segala aktivitasnya, baik yang berkenaan dengan ekonomi maupun yang lainnya.

b. Sumber daya alam adalah amanat

Harta kekayaan yang didapat dari pengelolaan bumi dan isinya adalah semata-mata hanya titipan atau amanah dari Allah SWT. oleh sebab itu dalam pengelolaan dan perdayagunaannya harus didasarkan prinsip kesejahteraan umat, kaidah halal-haram, dan tidak boros.

c. Gaya hidup sederhana

Islam menghendaki bahwa dalam penggunaan harta kekayaan, manusia hendaklah tidak bersikap boros dan sia-sia. Oleh sebab itu gaya hidup (life style) yang diajarkan Islam adalah kesederhanaan. Dalam Al-Qur'an Allah swt, menyatakan :

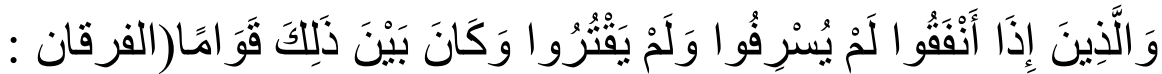

${ }^{15}$ Imam Munawir, Posisi Islam Ditengah Pertarungan Ideologi dan Keyakinan, (Surabaya:PT. Bina Ilmu, 1986), 22

${ }^{16}$ M. Umer Capra, Islam dan Tantangan Ekonomi: Islamisasi Ekonomi Kotemporer, Alih Bahasa Nur Hadi Ihsan, (Surabaya : Risalah Gusti, 1999), 224-235

I32| A1-Iqtishod Volume. 9/No. 2/Juli 202I 
Artinya : "Dan orang-orang yang apabila membelanjakan (harta), mereka tidak berlebih-lebihan, dan tidak (pula) kikir, dan adalah (pembelanjaan itu) di tengah-tengah antara yang demikian.".(QS. Al-Furqan :67). ${ }^{17}$

Ketiga, Al-Adl (keadilan). Keadilan merupakan sesuatu yang tidak dapat dikompromikan, artinya keadilan mempunyai urgensi yang teramat besar dalam kahidupan manusia. ${ }^{18}$ Manusia bisa hidup dalam kesusahan dan kelaparan, akan tetapi manusia tidak akan mampu bertahan hidup dalam ketidakadilan. Dalam konteks ekonomi Islam, keadilan disini adalah keadilan yang berarti kebebasan yang bersyarat Islami. Kebebasan yang tidak terbatas akan mengakibatkan ketidakserasihan dalam masyarakat. Jurang pemisah antara kaya dan miskin akan semakin tajam. Oleh sebab itu, nilai-nilai keadilan haruslah senantiasa menjadi landasan dalam setiap kegiatan ekonomi.

Implikasi dari nilai-nilai keadilan ini adalah :

a. Kebebasan manusia

Islam memandang bahwa setiap manusia adalah dikaruniahi oleh Allah swt kebebasan untuk menentukan dirinya sendiri. Begitu juga ketika Rasulullah diutus ke bumi juga untuk membebaskan manusia. Oleh sebab itu tindakan yang bertentangan dengan hakekat kebebasan manusia seperti perbudakan adalah bertentangan dengan ajaran Islam. Walaupun demikian kebebabasan yang dimaksud adalah kebebasan yang terbatas. artinya kebebasan itu dibatasi oleh nilai-nilai etika dalam berbagai aktivitas ekonomi, termasuk di dalamnya kaidah halal-haram. ${ }^{19}$

b. Perolehan penghasilan dari sumber-sumber yang baik.

Islam mengajarkan untuk mencari harta kekayaan, namun cara dan sumber harta kekayaan tersebut haruslah sesuai dengan tuntunan syari'ah seperti berdagang yang terbebas dari riba.

${ }^{17}$ QS. Al-Furqan (25):67

${ }^{18}$ Heri Sudarsono, Konsep Ekonomi Islam: Suatu Pengantar, (Yogyakarta: Ekonsia, 2003), I09

${ }^{19}$ Mustafa Kamal (edt), Wawasan Islam Dan Ekonomi: Bunga Rampai, (Jakarta: UI-Press, I997), 79

Volume. 9/No. 2/Juli 202I A1-Iqtishod | 133 
Konsep Distribusi Pendapatan ....

c. Distribusi pendapatan dan kekayaan yang adil.

Harta kekayaan yang telah di dapat haruslah didistribusikan secara merata pada masyarakat. Sebab, ketidakmerataan distribusi pendapatan akan merusak harmonisasi hubungan setiap manusia. Oleh sebab itu, Islam mensyariatkan zakat pada setiap manusia di samping sadaqah dan infaq. Dalam al-Qur'an dinyatakan :

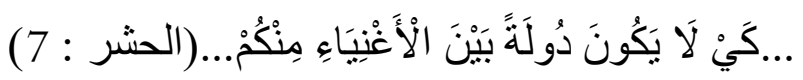

Artinya : "...Supaya harta itu jangan hanya beredar di antara orangorang kaya saja diantara kamu..."(QS. Al-Hasyr : 7). ${ }^{20}$

d. Pertumbuhan dan stabilitas

Ketiga prinsip dasar di atas, al-Tauhid, Khilafah dan al-Adl adalah suatu kebulatan nilai yang integral yang tidak bisa di pisahkan antara satu dengan yang lainnya. Ketiga prinsip dasar tersebut terefleksikan dalam nilai-nilai universal yang melatar belakangi keberadaan dan operasionalisasi ekonomi Islam.

\section{Asas Ekonomi Islam}

Dari prinsip dasar ekonomi Islam di atas, yang merupakan nilai-nilai universal yang mendasari kerangka kerja dan proses operasionalisasi ekonomi Islam, maka dapat dilihat bahwa asas dari ekonomi Islam adalah :

a. Kepemilikan ganda (Multiownership)

Artinya selain mengakui adanya kepemilikan pribadi, ekonomi Islam juga mengakui adanya kepemilikan umum dan kepemilikan negara. Dengan kata lain, kepemilikan dalam ekonomi Islam adalah kepemilikan yang didasarkan pada maslahat individu dan maslahat umum. ${ }^{21}$

${ }^{20}$ QS. Al-Hasyr (59): 7

${ }^{21}$ Mustafa, Wawasan Islam Dan Ekonomi: Sebuah Bunga Rampai, (Jakarta: UI-Press, I997), II4

I34| Al-Iqtishod Volume. 9/No. 2/Juli 202I 
Sifat dari kepemilikan dalam ekonomi Islam adalah kepemilikan yang bersifat relatif. Artinya harta kekayaan yang didapat oleh manusia hanyalah sebatas karunia dan pemberian Allah swt saja. Kepemilikan yang mutlak hanyalah milik Allah swt saja. Oleh karena itu, penerimaan terhadap realitas kepemilikan mutlak manusia, adalah sangat bertentangan dengan ajaran Islam, yang dalam hal ini adalah konsep al-Tauhid.22

Di dalam Al-Qur'an Allah SWT. menyatakan :

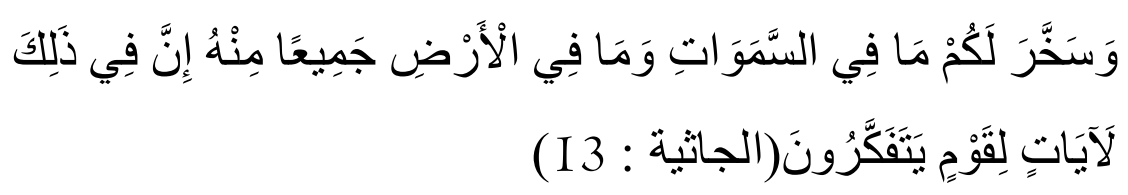

Artinya : "Dan Dia menundukkan untukmu apa yang ada di langit dan apa yang ada di bumi semuanya, (sebagai rahmat) daripada-Nya. Sesungguhnya pada yang demikian itu benar-benar terdapat tanda-tanda (kekuasaan Allah) bagi kaum yang berfikir".(QS. Al-Jaatsiyah: I3). ${ }^{23}$

b. Kebebasan Individu

Konsep kebebasan yang terdapat dalam ekonomi Islam adalah kebebasan yang dibatasi oleh kaidah-kaidah syar'i. Artinya dalam melakukan aktivitas ekonomi, walaupun manusia dalam pandangan ekonomi Islam diberikan kebebasan untuk berusaha dan mengumpulkan harta, namun kebebasan tersebut terikat dengan kaidah-kaidah pemerolehan dan pengelolaan harta yang telah digariskan oleh syara'.

Adapun kaidah-kaidah tersebut antara lain :

I) Ketentuan tentang halal dan haram

Artinya usaha yang dilakukan oleh setiap manusia dalam konteks ekonomi tidak boleh bertentangan dengan hukum syar'i, seperti larangan

${ }^{22}$ M. Umer, Etika Ekonomi Politik: Sebuah Bunga Rampai, Ainur R. Sophian (Editor), (Surabaya : Risalah Gusti,I997), 73

${ }^{23}$ QS. Al-Jaatsiyah (45): I3 
Konsep Distribusi Pendapatan ....

riba, memperoleh harta dengan jalan yang bathil seperti penipuan dan pencurian. ${ }^{24}$

Dalam Al-Qur'an Allah swt menyatakan :

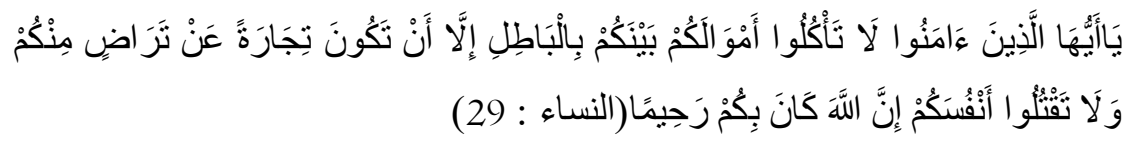

Artinya : "Hai orang-orang yang beriman, janganlah kamu saling memakan harta sesamamu dengan jalan yang batil, kecuali dengan jalan perniagaan yang berlaku dengan suka sama-suka di antara kamu. Dan janganlah kamu membunuh dirimu; sesungguhnya Allah adalah Maha Penyayang kepadamu". (QS. An-Nisa : 29). ${ }^{25}$

2) Kewajiban membayar zakat

Islam memandang, walaupun harta kekayaan yang kita dapatkan adalah hasil jerih payah kita sendiri. Namun sesungguhnya di balik harta kita terdapat hak-hak orang lain. Oleh sebab itu, selain untuk mensucikan harta dan memberikan hak-hak orang lain, maka Islam mewajibkan untuk berzakat.

3) Larangan penimbunan harta kekayaan

Sistem ekonomi Islam melarang individu mengumpulkan harta kekayaan secara berlebihan. Tidak seyogyanya seseorang yang telah memperoleh kekayaan karena usahanya sendiri kemudian hanya disimpan dan ditimbun tanpa dibelanjakan kembali. Sebab, dengan menimbun harta maka perputaran roda ekonomi akan berhenti, sehingga lambat laun kesejahteraan masyarakat akan turun. Oleh sebab itu, penimbunan harta adalah bertentangan dengan hukum syara' dan hukum ekonomi Islam.

c. Kebersamaan dalam menanggung kebaikan (at-Takaful al-Ijtima’’)

Islam mengakui kehidupan individu dan masyarakat saling berkaitan antara satu dengan lainnya. Dalam hal ini manusia selain di posisikan sebagai

${ }^{24}$ H. Ibrohim Lubis, Ekonomi Islam: Suatu Pengantar, (Jakarta :Kalam Mulia, I994), 164

${ }^{25}$ QS. An-Nisa(4): 29 
makhluk individu juga diposisikan sebagai makhluk sosial. Karakter masyarakat sangat dipengaruhi oleh karakter individu-individu. Oleh sebab itu, dalam konteks realisasi kebersamaan dalam menanggung kebaikan, hendaknya antara individu satu dengan lainnya dalam aktivitas ekonomi senantiasa mengedepankan kepentingan umum demi kesejahteraan bersama di atas kepentingan pribadi atau golongan.

Dalam Al-Qur'an Allah SWT. menyatakan :

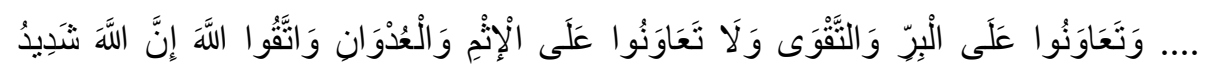
الْعِقَابِ(المائدة : 2 (2)

Artinya :"...Dan tolong-menolonglah kamu dalam (mengerjakan) kebajikan dan takwa, dan jangan tolong-menolong dalam berbuat dosa dan pelanggaran. Dan bertakwalah kamu kepada Allah, sesungguhnya Allah amat berat siksa-Nya (QS. Al-Maidah : 2)". ${ }^{26}$

\section{Metode Penelitian}

Pada penilitian ini, pendekatan yang digunakan adalah pendekatan Kuwalitatif. Data dihuimpun peneliti dengan membaca dan menelaah pemikiran para ahli dalam berbagai literatur yang ada yang berkaitan dengan fokus penelitian. Data yang telah dihimpun selanjutnya dianalisis dengan mengunakan teknik analisis deskriftif dengan logika deduktif-induktif.

\section{Hasil dan Pembahasan}

\section{Konsepsi Ekonomi Islam Tentang Kepemilikan}

Menurut Islam, keinginan manusia untuk mengumpulkan dan memperoleh harta kekayaan adalah fitrah setiap manusia. Manusia diciptakan Allah meliputi jasmani dan rohani. Oleh sebab itu, komponen yang menyusun manusia tersebut kebutuhannya haruslah terpenuhi.

Dorongan manusia untuk memperoleh harta kekayaan adalah tidak lain di sebabkan oleh adanya keberadaan kebutuhan jasmani manusia agar tetap eksis di

${ }^{26}$ QS. Al-Maidah (5): 2 
Konsep Distribusi Pendapatan ....

dunia. Dengan demikian, selain mengandung unsur fitrah manusia, dorongan untuk mengumpulkan harta kekayaan juga merupakan suatu keharusan. ${ }^{27}$

Islam tidak melarang individu-individu untuk memperoleh harta kekayaan, melainkan Islam hanya mengatur mekanisme pemerolehan harta kekayaan tersebut. Dengan kata lain, keberadaan hak milik individu diakui oleh Islam. Selain itu, Islam juga mengakui keberadaan kepemilikan umum dan kepemilikan negara. Dalam salah satu asas ekonomi di atas dinyatakan bahwa kepemilikan dalam ekonomi Islam adalah kepemilikan ganda (multiownership). ${ }^{28}$

\section{Sebab-Sebab Kepemilikan}

Sebab yang menjadikan seseorang memiliki harta yang sebelumnya bukan menjadi miliknya. Dengan kata lain, harta atau barang tersebut belum ada yang memilikinya. Adapun sebab-sebab kepemilikan harta, hukum syara' telah mengaturnya dan secara garis besar sebab-sebab kepemilikan dalam Islam terdapat 5 macam, yaitu : ${ }^{29}$

\section{a. Bekerja}

Pada hakekatnya, ketika manusia diutus dan didaulat menjadi khalifah, sebenarnya merupakan isyarat Allah swt kepada manusia untuk mengelola dan mendayagunakan serta memelihara kekayaan yang terkandung dalam bumi dan alam semesta raya.

Pandangan Islam, yang memposisikan setiap individu sebagai khalifah mengkondisikan bahwa bumi beserta isinya adalah kepunyaan Allah semesta. Pergeseran yang terjadi, dari milik Allah ke milik manusia adalah semata-mata

${ }^{27}$ Taqyuddin an-Nabhani, Membangun Sistem Ekonomi Alternatif : Prespektif Islam, Alih Bahasa M. Mighfar Wachid, (Surabaya: Risalah Gusti, 2002), 65

${ }_{28}$ Mustafa Kamal, Wawasan Islam Dan Ekonomi: Sebuah Bunga Rampai, (Jakarta: UIPress, 1997), II4

${ }_{29}^{29}$ Taqyuddin an-Nabhani, Membangun Sistem Ekonomi Alternatif : Prespektif Islam, Alih Bahasa M. Mighfar Wachid, (Surabaya: Risalah Gusti, 2002), 73

I38| Al-Iqtishod Volume. 9/No. 2/Juli 202I 
kehendak Allah. Salah satu faktor penyebab terjadinya pergeseran tersebut adalah dengan kerja. ${ }^{30}$

Kerja yang dikehendaki oleh ekonomi Islam adalah bentuk kerja yang tidak bertentangan dengan hukum syara'. Dalam al-Qur'an dinyatakan :
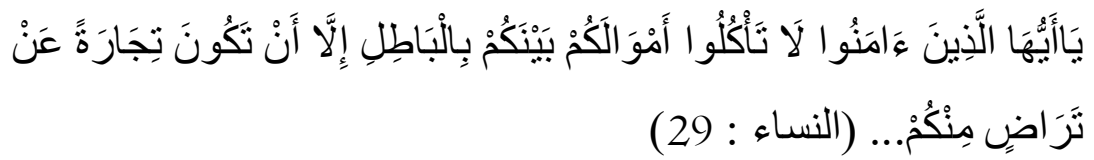

Artinya : "Hai orang-orang yang beriman, janganlah kamu saling memakan harta sesamamu dengan jalan yang batil, kecuali dengan jalan perniagaan yang berlaku dengan suka sama-suka di antara kamu... "(QS. An-Nisa' : 29). ${ }^{31}$

Dari ayat diatas, nampaklah bahwa memperoleh harta dengan jalan yang bathil atau merugikan orang lain adalah dilarang oleh hukum syara'. Perbuatan-perbuatan yang bertentangan dengan syara' tersebut seperti mencuri, merampok ataupun menipu. Adapun aktivitas ekonomi yang di perbolehkan adalah dengan jalan perniagaan yang di dasarkan atas sikap saling rela atau suka sama suka.

\section{b. Warisan}

Sebab kedua yang bisa menjadikan seseorang memiliki harta adalah dengan melalui harta waris. Waris merupakan bagian dari ajaran Islam yang wajib untuk dilaksanakan oleh setiap umat Islam. dalam Al-Qur'an Allah swt menyatakan :

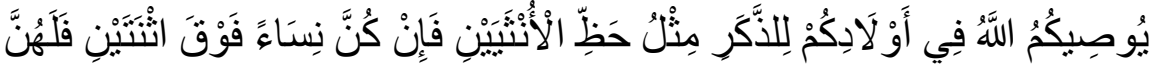

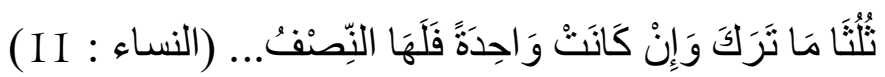

${ }^{30}$ Kerja sebagai salah satu sebab kepemilikan merupakan sebab yang memerlukan ikhtiyar (usaha) dalam pewujudannya. Usaha tersebut dalam literatur fikih mua'malah terdiri atas 2 macam yaitu ihrazul mubahat (menguasai benda mubah) dan aqad. Ihrazul mubahat disyaratkan dua hal yaitu tidak boleh pada benda yang telah diihrazkan oleh orang lain dan adanya maksud tamalluk. Sedangkan Aqad terdiri atas Aqad jabariyah dan Istimlak. Lihat Hasbi ash-Siddieqy, Pengantara Fikih Mua'malah, h. 9-IO

${ }^{31}$ QS. An-Nisa'(4) : 29 
Konsep Distribusi Pendapatan ....

Artinya :" Allah mensyari atkan bagimu tentang (pembagian pusaka untuk) anak-anakmu. Yaitu: bahagian seorang anak lelaki sama dengan bahagian dua orang anak perempuan; dan jika anak itu semuanya perempuan lebih dari dua, maka bagi mereka dua pertiga dari harta yang ditinggalkan; jika anak perempuan itu seorang saja, maka ia memperoleh separo harta...." (QS. AnNisa' : II $)^{32}$

Dari ayat diatas, nampaklah bahwa yang dikehendaki Islam ketika seseorang telah meninggal dunia dan meninggalkan harta baik dalam jumlah yang banyak atau sedikit, seyogyanya harta tersebut dibagikan kepada keturunannya atau karib kerabat yang terdekat. Sehingga harta kekayaan yang semasa orang itu hidup terkumpul padanya. Maka hendaknya ketika ia meninggal harta tersebut tidak terkumpul setelah orang tersebut meninggal. ${ }^{33}$

Keadaan ini memungkinkan orang lain untuk mengambil harta tersebut dengan jalan yang tidak sah. Oleh sebab itu, walaupun Islam melalui AlQur'an dan Al-Hadits telah menentukan orang-orang yang berhak menerima waris. Namun terkadang menjadi masalah, ketika si mayit meninggalkan ahli waris yang tidak bisa menghabiskan secara penuh harta tersebut. Sehingga dari pada itu, Islam memberikan pedoman dalam pembagian harta peninggalan si mayit. Aturan-aturan tersebut antara lain : ${ }^{34}$

a. Apabila si mayit meninggalkan ahli waris yang dapat menghabiskan harta peninggalan si mayit. Maka pembagian harta dilakukan sesuai dengan hukum waris.

b. Apabila si mayit meninggal hanya meninggalkan ahli waris yang tidak dapat menghabiskan harta pusaka, maka sisa harta dari pembagian tersebut dimasukkan baitul mal seperti : ahli waris hanya satu orang istri atau seorang suami.

${ }^{32}$ QS. An-Nisa'(4) : II

${ }^{33}$ Taqyuddin an-Nabhani, Membangun Sistem Ekonomi Alternatif : Prespektif Islam, Alih Bahasa M. Mighfar Wachid, (Surabaya: Risalah Gusti, 2002), II8

${ }^{34}$ H. Ibrahim K Lubis, Ekonomi Islam: Suatu Pengantar, (Jakarta :Kalam Mulia, I994), 223

I40| Al-Iqtishod Volume. 9/No. 2/Juli 202I 
c. Apabila tidak terdapat ahli waris, maka seluruh harta dimasukkan baitul mal

Dari sini, nampaklah bahwa waris merupakan salah satu sebab yang bisa menjadikan seseorang memiliki harta. Oleh sebab itu, seseorang yang memperoleh harta melalui jalan waris ini, maka pada hakekatnya secara syar'i seseorang tersebut telah memilikinya.

\section{c. Kebutuhan akan harta untuk menyambung hidup.}

Sebab yang ketiga adalah kebutuhan akan harta untuk menyambung hidup. Manusia yang mengemban misi sebagai khalifah di bumi dibekali oleh Allah swt dengan diciptakannya bumi beserta isinya. Kekhalifahan manusia hendaknya dipahami dalam konteks pemakmuran bumi beserta isinya. Upaya pendayagunaan dan pengelolaan alam dalam Islam sangatlah di anjurkan. Oleh sebab itu, salah satu bentuk pendayagunaan dan pengelolaan alam ini adalah dengan bekerja.

Pada hakekatnya, setiap manusia mempunyai hak untuk hidup. Oleh karena itu, dalam kerangka untuk mempertahankan hidup tersebut manusia tentunya memerlukan materi atau harta kekayaan. Dalam Al-Qur'an Allah SWT menyatakan :

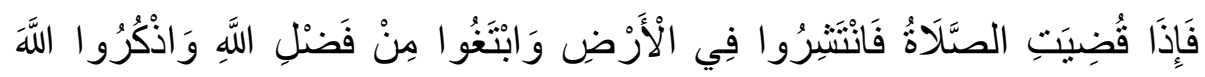

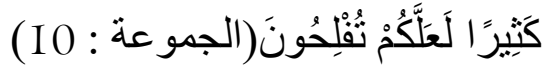

Artinya: "Apabila telah ditunaikan sembahyang, maka bertebaranlah kamu di muka bumi; dan carilah karunia Allah dan ingatlah Allah banyak-banyak supaya kamu beruntung. (QS. Al-Jumu'ah : I0).35

Dari ayat di atas nampaklah bahwa Islam bukan hanya menganjurkan untuk beribadah kepada Allah swt saja, melainkan Islam juga memerintahkan untuk mencari rizki atau harta kekayaan di bumi. Akan tetapi, ketika seseorang tidak mampu bekerja atau bekerja tapi hasilnya tidak mencukupi

${ }^{35}$ QS. Al-Jumu’ah (62): I0

Volume. 9/No. 2/Juli 202I Al-Iqtishod | I4I 
Konsep Distribusi Pendapatan ....

kebutuhannya, maka disinilah peranan umat Islam sebagai satu kesatuan untuk saling membantu dan menolong sesama. ${ }^{36}$

Instrumen yang diberikan oleh Islam dalam hal ini adalah seperti zakat, infaq, sadaqah ataupun melalui Baitul Maal. Negara sebagai institusi yang mempunyai kewajiban untuk mensejahterakan kehidupan rakyatnya, wajib memperhatikan nasib orang-orang yang tidak mempunyai pekerjaan. Oleh sebab itu, pada hakekatnya pemimpin adalah pelayan bagi rakyat.

Dalam sebuah hadits Rasulullah saw bersabda :

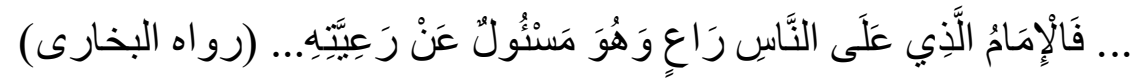

"...Imam yang menjadi pemimpin manusia, adalah (laksaana) pengembala. Dan hanya dialah yang bertanggung jawab terhadap (urusan) rakyatnya...". (HR. Imam Bukhari dari Abdullah ibn Umar). ${ }^{37}$

\section{d. Pemberian harta negara kepada rakyat ${ }^{38}$}

Yang termasuk dalam kategori sebab kepemilikan pemberian harta negara kepada rakyat adalah harta yang diamblikkan dari Baitul Maal. Sebagaimana dalam hadits diatas, negara mempunyai kewajiban untuk memenuhi hajat hidup rakyatnya.

Dalam hal ini, ketika negara mengambil harta dari Baitul Maal untuk diberikan kepada seseorang, maka harta tersebut pada hakekatnya telah menjadi milik orang tersebut. Seperti pemberian tanah oleh negara pada individu atau rakyat. Selain itu, pemberian harta oleh negara pada rakyat juga bisa dari harta perampasan perang (ghanimah).

\section{e. Harta yang di peroleh tanpa kompensasi harta atau tenaga}

${ }^{36}$ A. Qodri Azizi, Membangun Fondasi Ekonomi Umat: Meneropong Prospek Perkembangannya Ekonomi Islam, (Yogyakarta : Pustaka Pelajar, 2004), 28

${ }^{37}$ Imam Bukhari, Shahih Bukhari, Kitab Ahkam, Juz 7, h. 104

${ }_{38}$ Muhammad Kambali, "Analisis Peran Negara Di Bidang Ekonomi Dalam Prespektif Sistem Kapitalisme, Sosialisme, Dan Ekonomi Islam,” JES (Jurnal Ekonomi Syariah), 2016, https://doi.org/I0.30736/jes.vIiI.2. 
Harta yang di dapat tanpa adanya kompensasi atau kerja, dalam hal ini terdiri atas lima hal, yaitu :

I) Karena hubungan pribadi. Baik semasa waktu hidup maupun salah satunya meninggal, harta semacam ini adalah seperti Hibbah dan hadiah yang di dapatkan sewaktu hidup, atau wasiat dan waris yang di dapat ketika salah satu meninggal dunia.

2) Karena diyat ${ }^{39}$ atau denda yang di dapatkan seseorang karena kemadlaratan yang telah menimpanya.

3) Mahar dalam akad nikah

${ }^{39}$ Diyat adalah tebusan yang merupakan kompensasi dari pihak pelaku kejahatan kepada penderita. Dalam Al-Qur'an di jelaskan "Dan barang siapa membunuh orang mukmin, karena keluru (hendaklah) ia memerdekakan seorang budak yang beriman serta membayar diyat yang diserahkan pada keluarganya”. (QS. An-Nisa : 92), Sayyid Sabiq, Fiqih Sunnah, Juz I0. h. 94 
Konsep Distribusi Pendapatan ....

4) Barang temuan (luqathah). ${ }^{40}$

5) Santunan negara pada pejabat atau orang yang yang dianggap berjasa.

6) Tawalud min mamluk yaitu segala sesuatu yang terjadi dari benda yang dimiliki, menjadi hak bagi yang memiliki benda tersebut, seperti binatang yang beranak atau bulu domba yang menjadi pemilik domba. ${ }^{41}$

\section{Konsepsi Ekonomi Islam Tentang Distribusi Pendapatan}

Distribusi pendapatan sebagai kunci pokok dalam setiap sistem ekonomi, apakah Islam, kapitalis, sosialis maupun komunis, merupakan tolok ukur apakah sistem ekonomi tersebut efektif atau tidak dalam hal mensejahterakan rakyat. Dalam istilah konvensional, distribusi barang/ pendapatan merupakan dalam sistem ekonomi. ${ }^{42}$

Dalam prespektif ekonomi Islam, Distribusi pendapatan harus memperhatikan dua hal pokok yakni keseimbangan ekonomi dalam masyarakat dan larangan penimbunan harta.

\section{Keseimbangan ekonomi dalam masyarakat.}

Ekonomi Islam Memandang bahwa keseimbangan harta dalam masyarakat, urgensinya teramatlah besar. Dalam hal ini, produksi barangbarang yang terdapat dalam masyarakat haruslah terdistribusi secara merata dalam masyarakat. Sirkulasi harta dalam masyarakat hendaknya tidak terjadi pada sekelompok orang saja.

Dalam Al-Qur'an Allah swt menyatakan :

${ }^{40}$ Luqathah (barang temuan) haruslah diumumkan terlebih dahulu selama satu tahun, dalam jangka waktu itu tidak ada yang mencarinya, maka barang tersebut menjadi milik orang yang menemukan barang tersebut. Walaupun demikian, luqathah tidak boleh dari barang orang yang sedang ihram atau haji. Rasulullah bersabda: "Dan hendaklah tidak dijadikan "Luqathah" (barang temuan) harta yang jatuh, kecuali disimpan” (HR. Imam Bukhari), Taqyyuddin, Membangun....., h. I26 lihat juga H. Ibrahim, Ekonomi......., h. 285

${ }^{41}$ Lihat Ash-Siddieqy, pengantar.........., h. I2

${ }_{42}$ Pembahasan permasalahan fundamental dalam perekonomian, penulis telah memaparkannya pada Bab I tentang pendahuluan dalam latar belakang masalah. Dalam istilah konvensional permasalahan ini di kenal dengan "The Three Fundamental and Interdependent Economic Problem", yang terdiri atas What, How dan For Whom. Lihat Suherman Rosyidi, Pengantar Teori Ekonom: Pendekatan Kepada Teori Ekonomi Makro dan Mikro, Cet.II, h. IO 


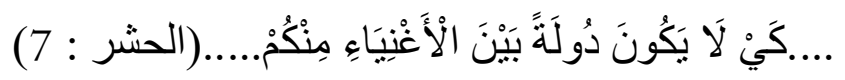

Artinya : "Supaya harta itu jangan hanya beredar diantara orang -orang kaya saja diantara kamu”. (QS. Al-Hasyr : 7) ${ }^{43}$

Sirkulasi harta yang hanya terjadi pada sekelompok orang saja, akan melahirkan kesejangan dalam masyarakat. Yang kaya makin kaya, sedangkan yang miskin makin tergilas dalam roda-roda perekonomian sebagai konsekwensi logis atas ketidak tersediaannya modal (harta). Oleh sebab itu, interaksi sosial dalam ranah ekonomi haruslah senantiasa di dasarkan pada prinsip keadilan.

Keberadaan keadilan dalam masyarakat mengkondisikan bahwa setiap individu mempunyai peluang dan hak yang sama dalam memanfaatkan alamseisinya. Alat-alat produksi hendaknya tidak tersentral pada sekelompok orang saja. Pemerataan ekonomi dan kesejahteraan umat merupakan visi ekonomi Islam. ${ }^{44}$

Kekayaan haruslah beredar secara merata dan adil dalam seluruh elemen masyarakat, layaknya darah yang beredar dalam jasad manusia. Stabilitas perekonomian sangatlah ditentukan oleh konstruksi keadilan dalam produksi dan distribusi harta. Oleh sebab itu, kesejahteraan umat sangatlah bergantung pada mekanisme distribusi harta yang merata dan adil. ${ }^{45}$

Salah satu akibat ketidak seimbangan harta dalam masyarakat adalah timbulnya kemiskinan dan kesenjangan sosial. Kemiskinan dalam pandangan Islam adalah sebuah bahaya yang teramat menakutkan. Kemiskinan yang melanda masyarakat akan mengakibatkan dampak yang besar. Dampak tersebut bisa berimbas pada keyakinan (akidah), akhlak maupun interaksi

\footnotetext{
${ }^{43}$ QS. Al-Hasyr (59): 7

${ }^{44}$ M. Umar Chapra, Etika Ekonomi Politik: Sebuah Bunga Rampai, Ainur R. Sophian (Editor), (Surabaya : Risalah Gusti,I997), 87

${ }^{45}$ M. Umar Chapra, "Economic Development in Muslim Countries:," in Contribution of Islamic Thought to Modern Economics (Vol. 2), 2019, https://doi.org/I0.2307/j.ctvkc66r2.6.
} 
Konsep Distribusi Pendapatan ....

individu dalam masyarakat. Selain itu, kemiskinan juga berakibat pada pemikiran, keluarga, kebudayaan dan umat. ${ }^{46}$

Kemiskinan merupakan ancaman yang serius terhadap bangunan akidah seseorang. Kelaparan dan kesengsaraan yang di alami seseorang bisa berakibat pada tumbuhnya keraguaan di hati seseorang terhadap kebijakan Allah swt mengenai pembagian rizki. Pada akhirnya, dengan tumbuhnya keraguan manusia atas kebijakan Allah dalam pembagian rizki akan berujung pada tercerabutnya akar keimanan seseorang. Oleh sebab itu, kemiskinan haruslah dihilangkan dan hal itu merupakan tanggung jawab kita bersama selaku umat Islam.

Dalam Al-Qur'an Allah swt menyatakan :

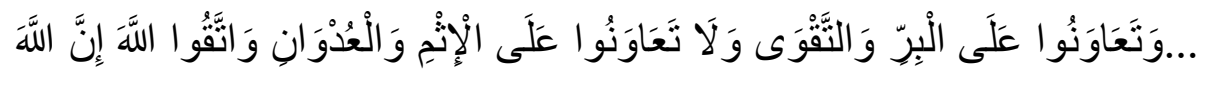

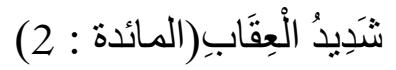

Artinya :"...Dan tolong-menolonglah kamu dalam (mengerjakan) kebajikan dan takwa, dan jangan tolong-menolong dalam berbuat dosa dan pelanggaran. Dan bertakwalah kamu kepada Allah, sesungguhnya Allah amat berat siksaNya”. (QS. Al-Maidah : 2).77

Dalam upaya untuk mewujudkan keseimbangan dalam masyarakat, maka negara adalah institusi yang berkewajiban dalam hal ini. Aktivitas-aktivitas individu dalam kegiatan ekonomi, mungkin tidak selalu menjaga dan menjalankan prinsip keadilan. Motif ekonomi yang menghendaki seseorang untuk memperoleh keuntungan yang besar, melahirkan kecenderungan untuk mengabaikan kepentingan publik dan masalahah umat. Oleh karena itu, supaya kepentingan individu dan publik berjalan seimbang, maka negara harus turut serta menjaga kelestarian maslahah individu dan maslahah umat. ${ }^{48}$

46 Yusuf Qhardawi, Kiat Islam Mengentasakan Kemiskinan, Alih Bahasa Syafril Halim, (Jakarta: Gema Insani Press, 1995), 23

${ }^{47}$ QS. Al-Maidah (5): 2

${ }^{48}$ Syafiq A. Alvi dan Amer al-Roubaie, Strategi Pertumbuhan Ekonomi yang Berkesinambungan :dalam Perspektif Islam, Islamia, No. 5, h. 96

I46 | Al-Iqtishod Volume. 9/No. 2/Juli 202I 
Di sisi lain, golongan masyarakat yang tidak mampu untuk memenuhi kebutuhan hidupnya, maka negara haruslah bertanggungjawab dalam memenuhi kebutuhan golongan masyarakat tersebut. Sebab, dalam konsepsi Islam negara adalah pelayan bagi rakyatnya. Dalam hal ini, harta yang di pergunakan untuk menjaga keseimbangan ekonomi dalam masyarakat adalah harta yang berasal dari baitul maal. ${ }^{49}$ Dengan demikian, nampaklah bahwa ketimpangan sosial adalah sebagai akibat ketidak seimbangan ekonomi dalam masyarakat dan hal itu merupakan tanggung jawab kita selaku umat Islam yang merupakan satu kesatuan ibaratkan badan manusia yang harus saling tolong-menolong.

\section{Larangan Penimbunan Harta}

Sistem ekonomi Islam, melarang individu mengumpulkan harta secara berlebihan. Sebab, dengan adanya pengumpulan harta secara berlebihan, maka akan berakibat pada mandegnya roda perekonomian. Pengumpulan harta disini, di pahami bahwa dengan melakukan pengumpulan harta secara besarbesaran, maka seseorang akan dapat mengeruk keuntungan dari orang lain.

Dengan kata lain, pengumpulan harta tersebut bukan di tujukan untuk memenuhi kebutuhan dalam rangka mempertahankan hidup. Melainkan di dasarkan tanpa adanya kebutuhan dalam pengumpulannya. Oleh sebab itu, pengumpulan harta secara berlebih-lebihan tanpa adanya tujuan untuk pemenuhan kebutuhan hidup adalah tindakan penimbunan harta yang dicela oleh Islam. ${ }^{50}$

Dalam Al-Qur'an Allah swt menyatakan :

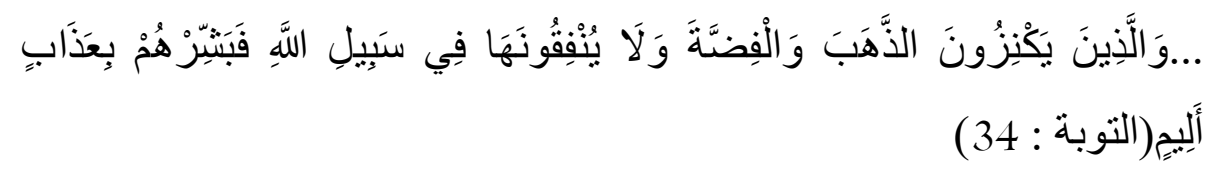

${ }^{49}$ Dalam konsepsi Islam, harta yang dipergunakan untuk menjaga keseimbangan ekonomi dalam masyarakat eloh negara adalah berasal dari baitul maal. Yang mana baitul maal itu sendiri pemasukannya berasal dari fai" ghanimah, anfal, jizyah, kharaj, pajak dan zakat. Lihat Taqyuddin , Membangun......, h.253 Ilmu, I986), II5

${ }^{50}$ Imam Munawir, Posisi Islam Ditengah Pertarungan Ideologi dan Keyakinan, (Surabaya:PT. Bina 
Konsep Distribusi Pendapatan ....

Artinya : "Dan orang-orang yang menimbun emas dan perak dan tidak menafkahkannya pada jalan Allah, beritakanlah kepada mereka bahwa mereka akan mendapat siksaan yang pedih”. (QS. At-Taubah : 34) ${ }^{51}$

Penggambaran dalam ayat diatas, menggunakan isitlah penimbunan emas dan perak. Namun bukan berarti penimbunan yang tidak berbentuk emas dan perak bukan termasuk kategori penimbunan harta. Melainkan penggambaran dalam al-Qur'an dalam bentuk emas dan perak haruslah di pahami dalam makna yang luas. Dengan kata lain, substansi dari penggambaran dalam alQur'an di atas adalah semata-mata tindakan pengumpulan harta yang di tujukan untuk menguntungkan kepentingan pribadi yang mengakibatkan kerugian orang lain maupun masyarakat. ${ }^{52}$

Dalam pandangan Islam, penimbunan harta dan penyimpanan harta adalah tidak sama. Perbedaan antara penimbunan (kanz) dan penyimpanan (saving) adalah kalau penimbunan (kanz) bertujuan untuk mengumpulkan harta tanpa adanya kebutuhan sehingga mengakibatkan kerugian publik dan mandegnya roda perekonomian. Sedangkan penyimpnan (saving) adalah pengumpulan harta yang di tujukan untuk pemenuhan akan kebutuhan hidup manusia. Artinya dengan adanya tindakan saving masyarakat tidak akan di rugikan serta roda perekonomian akan tetap berjalan. Sebab, tindakan saving semata-mata untuk pemenuhan kebutuhan manusia, sehingga perputaran uang akan terus berjalan. ${ }^{53}$

\section{E. Simpulan}

Dalam ekonomi Islam, keinginan manusia untuk mengumpulkan dan memperoleh harta kekayaan adalah fitrah setiap manusia. Manusia diciptakan Allah meliputi jasmani dan rohani. Oleh sebab itu, komponen yang menyusun manusia

${ }^{51}$ QS. At-Taubah (9) : 34

${ }^{52}$ H. Ibrahim Lubis, Ekonomi Islam: Suatu Pengantar, (Jakarta :Kalam Mulia, I994), 160

53 Taqyyuddin An-Nabhani, Membangun Sistem Ekonomi Alternatif : Prespektif Islam, Alih Bahasa M. Mighfar Wachid, (Surabaya: Risalah Gusti, 2002), 277

I48| Al-Iqtishod Volume. 9/No. 2/Juli 202I 
tersebut kebutuhannya haruslah terpenuhi. Dorongan manusia untuk memperoleh harta kekayaan adalah tidak lain di sebabkan oleh adanya keberadaan kebutuhan jasmani manusia agar tetap eksis di dunia. Dengan demikian, selain mengandung unsur fitrah manusia, dorongan untuk mengumpulkan harta kekayaan juga merupakan suatu keharusan.

Islam tidak melarang individu-individu untuk memperoleh harta kekayaan, melainkan Islam hanya mengatur mekanisme pemerolehan harta kekayaan tersebut. Dengan kata lain, keberadaan hak milik individu diakui oleh Islam. Selain itu, Islam juga mengakui keberadaan kepemilikan umum dan kepemilikan negara. Dalam salah satu asas ekonomi di atas dinyatakan bahwa kepemilikan dalam ekonomi Islam adalah kepemilikan ganda (multiownership).

Konsep distribusi pendapatan dalam sistem ekonomi Islam mengharuskan pada dua hal supaya keadilan sebagai prinsip ekonomi Islam termanivestasi didalamnya. Dua hal tersebut adalah adanya keseimbangan harta dalam masyarakat dan larangan adanya penimbunan harta.

\section{F. Daftar Pustaka}

Chapra, M. Umar. “Economic Development in Muslim Countries:” In Contribution of Islamic Thought to Modern Economics (Vol. 2), 2019. https://doi.org/I0.2307/j.ctvkc66r2.6.

M. Umer Capra, Islam dan Tantangan Ekonomi: Islamisasi Ekonomi Kotemporer, Alih Bahasa Nur Hadi Ihsan, (Surabaya : Risalah Gusti, I999), 217

M. Umer, Etika Ekonomi Politik: Sebuah Bunga Rampai, Ainur R. Sophian (Editor), (Surabaya : Risalah Gusti,I997), 73

Kambali, Muhammad. "Analisis Peran Negara Di Bidang Ekonomi Dalam Prespektif Sistem Kapitalisme, Sosialisme, Dan Ekonomi Islam.” JES (Jurnal Ekonomi Syariah), 2016. https://doi.org/I0.30736/jes.vIiI.2. PENDAPATAN DALAM SISTEM EKONOMI KAPITALIS.” Jurnal Studi Keislaman, 2015. 
Konsep Distribusi Pendapatan ....

Ahmad Mushthafa al-Maraghi, Tafsir al-Maraghi, Alih Bahasa Bahrun Abu Bakar, jus 27, cetakan ke-2, (Semarang:Toha Putra, I992), 24

M. Hasbin Amiruddin, Konsep Negara Islam Menurut Fazlur Rahman, (Yogyakarta:UIIPress, 2000), 2-3.

Abdul Mughist, Epistemologi Ilmu Ekonomi Islam, Hermeneia : Jurnal Kajian Islam Interdisipliner, vol. 2, No. 2, Juli-Desember, h. I74

Mahmud Abu Saud, Garis-Garis Besar Ekonomi Islam, Alih Bahasa Syed Ahmad Ali , (Jakarta: Gema Insani Press,I99 I), I7

M. Amin Rais, Cakrawala Islam:Antara Cita Dan Fakta, (Bandung: Mizan,I99 I), 96

Taqyuddin An-Naabhani, Membangun Sistem Ekonomi Alternatif : Prespektif Islam, Alih Bahasa M. Mighfar Wachid, (Surabaya: Risalah Gusti, 2002), 50

Imam Munawir, Posisi Islam Ditengah Pertarungan Ideologi dan Keyakinan, (Surabaya:PT. Bina Ilmu, I986), 22

Heri Sudarsono, Konsep Ekonomi Islam: Suatu Pengantar, (Yogyakarta: Ekonsia, 2003), I09

Mustafa Kamal (edt), Wawasan Islam Dan Ekonomi: Bunga Rampai, (Jakarta: UIPress, I997), 79

H. Ibrohim Lubis, Ekonomi Islam: Suatu Pengantar, (Jakarta :Kalam Mulia, I994), I64

A. Qodri Azizi, Membangun Fondasi Ekonomi Umat: Meneropong Prospek Perkembangannya Ekonomi Islam, (Yogyakarta : Pustaka Pelajar, 2004), 28

Imam Bukhari, Shahih Bukhari, Kitab Ahkam, Juz 7, h. I04

Yusuf Qhardawi, Kiat Islam Mengentasakan Kemiskinan, Alih Bahasa Syafril Halim, (Jakarta: Gema Insani Press, I995), 23

Syafiq A. Alvi dan Amer al-Roubaie, Strategi Pertumbuhan Ekonomi yang Berkesinambungan :dalam Perspektif Islam, Islamia, No. 5, h. 96 